\title{
Hydrogeochemistry and spatio-temporal changes of a tropical coastal wetland system: Veli-Akkulam Lake, Thiruvananthapuram, India
}

\author{
K. S. Sajinkumar ${ }^{1}$ A. Revathy $^{1} \cdot$ V. R. Rani $^{2}$
}

Received: 16 February 2015/ Accepted: 25 August 2015/Published online: 7 September 2015

(c) The Author(s) 2015. This article is published with open access at Springerlink.com

\begin{abstract}
The backwater of Veli-Akkulam, adjoining the Arabian Sea in the south-west part of Indian Peninsula, is a coastal wetland system and forms an integral part of the local ecosystem. In addition to the usual marine interactions, this water body is subjected to anthropogenic interference due to their proximity to the Thiruvananthapuram City urban agglomeration. This paper showcases how an urban agglomeration alters wetland system located within a tropical monsoonal environment. Water samples from this lake together with different feeder streams reveal that the lake is under the threat to eutrophication. A spatio-temporal analysis has shown that the lake and adjacent wetlands are shrinking in a fast pace. Over a period of about seven decades, the lake has shrunk by $28.05 \%$ and the wetlands by $37.81 \%$. And hence, there is a pressing requirement of ecomanagement practices to be adopted to protect this lake.
\end{abstract}

Keywords Veli-Akkulam Lake · Hydrogeochemistry · Spatio-temporal variation $\cdot$ Eutrophication

\section{Introduction}

Brackish water lakes of Kerala, called 'kayals' (in native 'Malayalam' language) or backwaters or coastal lagoons, and its associated flood plains form the coastal wetland system of Kerala. The total estimated wetland area is

K. S. Sajinkumar

sajinks@yahoo.com; sajinks@gmail.com

1 Department of Geology, University of Kerala, Thiruvananthapuram 695 581, India

2 Central Ground Water Board, Thiruvananthapuram 695004 , India
127,930 ha comprising 34,200 ha of 'inland wetlands' and 93,730 ha 'coastal wetlands' (Nair 2007). It is generally believed that these coastal wetlands have evolved through gradual regression of the sea after the Holocene marine transgression (Bruckner 1989; Ravindrakumar et al. 1990; Thrivikramji et al. 2007; Nair 2007; Nair et al. 2010; Padmalal et al. 2010). Among the various states in India, Kerala stands first in having the largest area of wetlands (Nayar and Nayar 1997). Physiographically, all the brackish lakes are located in the coastal tract, whereas the freshwater lakes occupy the mid-land portion. The lowrelief coastal plain topography of Kerala is renowned for the presence of several backwaters of very special forms in plan view and unique orientation with respect to the modern shoreline (Sabu and Thrivikramji 2002). Backwaters play an important role in the field of transportation, fishing, navigation, irrigation and drinking water schemes in Kerala (Muraleedharan and Muraleedharan 2002). They also play a vital role in shaping the socio-economic and climatic condition of the state.

Many studies have been carried out on the Veli-Akkulam Lake which includes soil study (Slimmings 1997), an integrated environmental assessment (Muraleedharan Nair et al. 1998), methane emission and diurnal pattern (Divya 2007), heavy metal pollution monitoring using lichens (Salini 2007), lake morphology and water quality (Sheela et al. 2011), heavy metal (Swarnalatha et al. Swarnalatha et al. 2012) and extent of sea-level rise (Sheela et al. 2013). The studies, on a whole, indicate that the heavy metal content of Veli-Akkulam Lake is high and that the water quality depends on the morphometric features like mean depth, surface area, volume. These studies further show that the dilution capacity is very low for the Veli-Akkulam Lake and also that the nitrate and phosphate content of the lake is high. 
The present study mainly focuses on the hydrogeochemistry of this coastal wetland system as well as the streams feeding this lake. This study on the hydrogeochemistry will be of immense help in updating the existing ecological and environmental geochemical database of the lake. This lake is slowly dying due to eutrophication induced by the continuous inflow of effluents from the streams draining the urban agglomerate, and any addition to the knowledge base on the health of the lake is of immense importance in nurturing the lake back to health and also to prevent any further deterioration. As the lake is situated in between Thiruvananthapuram City and the nearby fast-developing information technology hub-Kazhakkuttam-where numerous skyscrapers have emerged and related constructional activities have resulted in filling up of various wetlands, a study on the spatio-temporal changes in the natural environment of the area is also a pressing requirement.

\section{Study area}

The Veli-Akkulam Lake, a famous tourist destination, is located about $8 \mathrm{~km}$ north of Thiruvananthapuram and fringes the Arabian Sea in the western coast of India
(Fig. 1). It is situated between $8^{\circ} 31^{\prime} 14^{\prime \prime}$ and $8^{\circ} 31^{\prime} 52^{\prime \prime}$ north latitudes and $76^{\circ} 53^{\prime} 12^{\prime \prime}$ and $76^{\circ} 54^{\prime} 06^{\prime \prime}$ east longitudes and is covered by the Survey of India topographic sheet $58 \mathrm{D} /$ 14/SE (on 1:25,000 scale). The total area of study is $135 \mathrm{~km}^{2}$ of which the lake occupies an area of $1.16 \mathrm{~km}^{2}$.

The Travancore-Shornanur (TS) Canal or Parvathy Puthanar (the erstwhile navigation canal connecting north and south Kerala) connects this lake with two estuariesKadinamkulam to the north and Thiruvallam to the south. Veli-Akkulam Lake is fed by Kannammoola stream, Kulathur stream, Amaizhanchan stream and Sreekaryam stream. These streams together with their tributaries drain the urban precincts of Thiruvananthapuram and finally debouch to the Veli-Akkulam Lake. Numerous dwellings and slums are situated all along these rivers. Sewage waste from the dwellings, domestic waste and other industrial waste have resulted in polluting these drainages as well as Veli-Akkulam Lake.

Geologically, the area forms a part of Kerala Khondalite Belt (KKB) characterized by the presence of khondalites and charnockites. Usually, these Precambrian rocks are overlain by Tertiary sediments (Soman 2002). Veli-Akkulam Lake and adjacent areas also expose Quaternary sediments

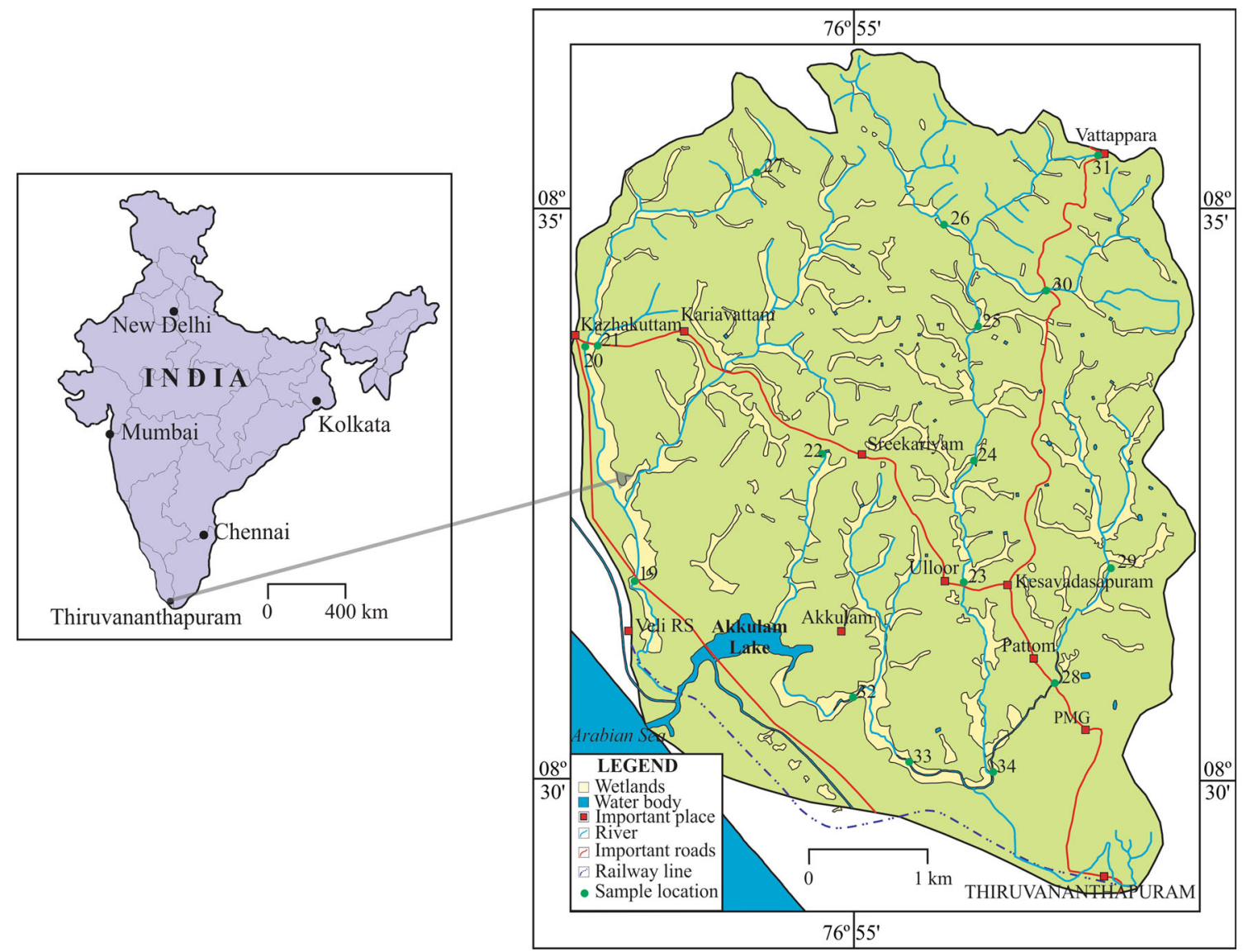

Fig. 1 Location map of the study area. Samples locations are also shown (samples 1-18 are collected from both the banks of the lake and are not shown here due to the scale limitations) 
Table 1 Physical parameters of water samples

\begin{tabular}{|c|c|c|c|c|c|}
\hline Sample no & Colour & Odour & Taste & Turbidity & Temperature $\left({ }^{\circ} \mathrm{C}\right)$ \\
\hline 1 & Grey colour & Odourless & Brackish & Turbidity & 27.75 \\
\hline 2 & Slightly grey & Odourless & Bitter & Slightly turbid & 30 \\
\hline 3 & Slightly clear & Odourless & Saline & Slightly turbid & 31 \\
\hline 4 & Slightly grey & Odourless & Bitter & Turbid & 30.5 \\
\hline 5 & Slightly clear & Odourless & Brackish & Turbid & 32.5 \\
\hline 6 & Slightly grey & Odourless & Brackish & Slightly turbid & 28.5 \\
\hline 7 & Grey colour & Odourless & Brackish & Slightly turbid & 29 \\
\hline 8 & Grey colour & Odourless & Brackish & Slightly turbid & 30 \\
\hline 9 & Slightly grey & Odourless & Saline & Turbid & 30.5 \\
\hline 10 & Slightly clear & Odourless & Bitter & Slightly turbid & 30 \\
\hline 11 & Slightly clear & Odourless & Brackish & Slightly turbid & 31 \\
\hline 12 & Grey colour & Odourless & Brackish & Slightly turbid & 30 \\
\hline 13 & Grey colour & Odourless & Brackish & Turbid & 32.5 \\
\hline 14 & Slightly clear & Odourless & Saline & Slightly turbid & 30 \\
\hline 15 & Slightly clear & Odourless & Saline & Slightly turbid & 32 \\
\hline 16 & Slightly clear & Odourless & Brackish & Slightly turbid & 32 \\
\hline 17 & Slightly clear & Odourless & Saline & Slightly turbid & 32.5 \\
\hline 18 & Slightly clear & Odourless & Saline & Slightly turbid & 32 \\
\hline \multicolumn{6}{|l|}{ Kulathur } \\
\hline 19 & Grey colour & Pungent & & Turbid & 26.5 \\
\hline 20 & Black & Pungent & & Highly turbid & 28.5 \\
\hline 21 & Black & Pungent & & Highly turbid & 29 \\
\hline 27 & Clear & Odourless & Good & Slightly turbid & 31 \\
\hline \multicolumn{6}{|c|}{ Amaizhanchan } \\
\hline 23 & Light black & Slightly Pungent & & Slightly turbid & 28.5 \\
\hline 24 & Clear & Odourless & Good & Clear & 28 \\
\hline 25 & Clear & Odourless & Good & Clear & 29 \\
\hline 26 & Clear & Odourless & Good & Clear & 28.5 \\
\hline 30 & Clear & Odourless & Good & Slightly turbid & 28.5 \\
\hline 31 & Clear & Odourless & Good & Slightly turbid & 30.5 \\
\hline \multicolumn{6}{|c|}{ Kannanmoola } \\
\hline 28 & Black colour & Pungent & & Turbid & 32 \\
\hline 29 & Clear & Odourless & Bitter & Slightly turbid & 31 \\
\hline \multicolumn{6}{|c|}{ Amaizhanchan-Kannanmoola confluence } \\
\hline 32 & Grey colour & Pungent & & Turbid & 31 \\
\hline 33 & Light black & Slightly Pungent & & Turbid & 30 \\
\hline 34 & Clear & Odourless & Brackish & Turbid & 31 \\
\hline \multicolumn{6}{|c|}{ Sreekariyam Thodu } \\
\hline 22 & Clear & Slightly Pungent & & Turbid & 28 \\
\hline
\end{tabular}

belonging to Viyyam Formation formed by laccustrine processes. Geomorphologically, these areas are influenced by coastal and marine activities. A bar separates this lake from the Arabian Sea which is usually opened during monsoon to prevent upstream flooding and inundation, and a new bar is naturally created by the long-shore currents after the monsoon. Marine ingressions are common.

\section{Methodology}

Thirty-four surface water samples (as shown in Fig. 1) were collected, which includes lake samples (18 nos) and samples from the streams (16 nos) that feed the lake, in order to understand the hydrogeochemistry of this wetland system. The physical parameters of water like colour, 
Table 2 Mean and range values of hydrogeochemical parameters

\begin{tabular}{|c|c|c|c|c|c|}
\hline \multirow[t]{2}{*}{ Parameter } & \multicolumn{2}{|l|}{ Range } & \multirow[t]{2}{*}{ Mean } & \multicolumn{2}{|l|}{ BIS } \\
\hline & Max & Min & & Highest desirable & No relaxation \\
\hline $\mathrm{pH}$ & 7.62 & 6.37 & 6.99 & $6.5-8.5$ & No relaxation \\
\hline $\mathrm{EC}(\mu \mathrm{S} / \mathrm{cm})$ & 4380 & 46.2 & 745.59 & - & - \\
\hline TDS (ppm) & 3900 & 34.4 & 552.81 & 500 & 2000 \\
\hline Salinity (ppt) & 2.57 & 0.034 & 0.414 & - & - \\
\hline Total Hardness (ppm) & 505 & 50 & 163.97 & 300 & 600 \\
\hline $\mathrm{K}^{+}(\mathrm{ppm})$ & 30 & 2 & 10.97 & - & - \\
\hline $\mathrm{Ca}^{2+}(\mathrm{ppm})$ & 114.22 & 10.02 & 32.29 & 75 & 200 \\
\hline $\mathrm{Mg}^{2+}(\mathrm{ppm})$ & 89.86 & 3.60 & 15.69 & 30 & 100 \\
\hline $\mathrm{Na}^{+}(\mathrm{ppm})$ & 930 & 18 & 113.64 & - & 200 \\
\hline $\mathrm{HCO}_{3}{ }^{-}(\mathrm{ppm})$ & 375 & 20 & 113.97 & - & - \\
\hline $\mathrm{Cl}^{-}(\mathrm{ppm})$ & 1583.3 & 49.7 & 191.81 & 250 & 1000 \\
\hline $\mathrm{NO}_{3}{ }^{-}(\mathrm{ppm})$ & 8.68 & 0 & 1.051 & 45 & 100 \\
\hline $\mathrm{SO}_{4}{ }^{2-}(\mathrm{ppm})$ & 143.41 & 8.12 & 39.67 & 200 & 400 \\
\hline $\mathrm{PO}_{4}{ }^{3-}(\mathrm{ppm})$ & 9.95 & 0 & 1.503 & - & - \\
\hline
\end{tabular}

odour, taste, turbidity and temperature were calculated in the field, immediately after sample collection. These water samples were analysed through various analytical methods like titration, spectrophotometer (Perkin Elmer Lambda 25 UV-Visible Spectrophotometer) and flame photometer (ESCIO Digital Clinical Flame Photometer) for quantifying the hydrogeochemistry at the Department of Geology, University of Kerala, using the standard techniques like APHA (1989). Further, the results are graphically represented in standard diagrams like Hill Piper (Piper 1953), US salinity (1954) and Wilcox (1955) for understanding the suitability of water for various uses.

Spatio-temporal changes of Veli-Akkulam Lake and land-use/land-cover changes were studied using Survey of India topographic sheets 58D/14 for the years 1942 (on 1:63,500 scale), 1990 (on 1:25,000) and the Google Earth Imagery of 2013. All the temporal data were analysed in a GIS environment using MapInfo Professional 10.5.

\section{Results and discussion}

\section{Hydrogeochemistry of the coastal wetland system}

This area offers an excellent example to study the spatial variation of geochemistry of a lake and its feeding streams within a small geographical area of about $135 \mathrm{~km}^{2}$. The results of the analysis of the 34 different water samples collected from both the lake and the stream are given in Tables 1, 2 and 3. Table 1 provides the physical parameters of the water samples. Since the lake is situated in the fringe of an urban area, the physical parameters reflect the influence of urbanization in surface water. There is a deterioration of quality of water as it travels down through the agglomeration. Most astonishing feature noticed in the water samples collected from feeder stream is that the odour and colour varies from odourless (mainly Amaizhanchan stream) to slightly pungent to pungent (mainly Kulathur stream) and clear to black towards the confluence. But the lake water samples are odourless and slightly clear to grey in colour.

The minimum, maximum and mean values of all hydrogeochemical constituents are tabulated and compared with Bureau of Indian Standards (BIS, 1991) and are given in Table 2. The comparison shows that only two locations (from Kulathur stream) show high variation from the BIS values. In the rest of the streams, all the constituents are within the permissible limit.

Table 3 provides the values of chemical constituents of all the samples of the feeder streams and lake in the study area. The physico-chemical constituents of the samples show wide variations, even within the lake as well as between different feeder streams. Of the different feeder streams, Kulathur stream (sample nos 20 and 21) shows the maximum values for majority of the constituents, whereas Kulathur stream (sample no 27) shows the minimum value. Such a major variation in the geochemistry of a watershed within an urbanized environment can be easily attributed to anthropogenic interferences. Dumping of waste materials in the streams is a common phenomenon in majority of the urban areas in developing nations, and the study area is no exception. The uniqueness of this city is the absence of a centralized waste collection or disposal as its only solid waste incinerator located at Vilapilsala $\left(8^{\circ} 32^{\prime} 20^{\prime \prime} \mathrm{N}\right.$; $77^{\circ} 02^{\prime} 19.5^{\prime \prime} \mathrm{E}$ ) is shut down due to local agitation. Hence, domestic wastes and sewerages together with industrial 
Table 3 Hydrochemical data of water samples collected from the study area

\begin{tabular}{|c|c|c|c|c|c|c|c|c|c|c|c|c|c|c|}
\hline Sample no. & $\mathrm{pH}$ & $\begin{array}{l}\text { Salinity } \\
\text { (ppt) }\end{array}$ & $\begin{array}{l}\mathrm{EC}(\mu \mathrm{s} / \\
\mathrm{cm})\end{array}$ & $\begin{array}{l}\text { TDS } \\
(\mathrm{ppm})\end{array}$ & $\begin{array}{l}\text { Total } \\
\text { hardness } \\
(\mathrm{ppm})\end{array}$ & $\begin{array}{l}\mathrm{Na}^{+} \\
(\mathrm{ppm})\end{array}$ & $\begin{array}{l}\mathrm{K}^{+} \\
(\mathrm{ppm})\end{array}$ & $\begin{array}{l}\mathrm{Ca}^{2+} \\
(\mathrm{ppm})\end{array}$ & $\begin{array}{l}\mathrm{Mg}^{2+} \\
(\mathrm{ppm})\end{array}$ & $\begin{array}{l}\mathrm{Cl}^{-} \\
(\mathrm{ppm})\end{array}$ & $\begin{array}{l}\mathrm{HCO}_{3}^{-} \\
(\mathrm{ppm})\end{array}$ & $\begin{array}{l}\mathrm{SO}_{4}^{2-} \\
(\mathrm{ppm})\end{array}$ & $\begin{array}{l}\mathrm{NO}_{3}^{-} \\
(\mathrm{ppm})\end{array}$ & $\begin{array}{l}\mathrm{PO}_{4}{ }^{3-} \\
(\mathrm{ppm})\end{array}$ \\
\hline 1 & 6.94 & 0.336 & 620 & 442 & 185 & 71 & 14 & 38.07 & 21.82 & 159.75 & 105 & 18.56 & 0 & 1.18 \\
\hline 2 & 7.24 & 0.271 & 501 & 357 & 145 & 65 & 12 & 28.05 & 18.19 & 106.5 & 110 & 34.04 & 0 & 2.45 \\
\hline 3 & 7.16 & 0.287 & 541 & 385 & 135 & 64 & 14 & 30.06 & 14.54 & 127.8 & 90 & 20.69 & 0.058 & 1.82 \\
\hline 4 & 7.27 & 0.292 & 545 & 386 & 155 & 62 & 15 & 36.07 & 15.75 & 127.8 & 165 & 20.76 & 3.684 & 1.26 \\
\hline 5 & 7.37 & 0.312 & 583 & 415 & 145 & 77 & 11 & 28.05 & 18.19 & 138.45 & 95 & 30.96 & 1.067 & 1.10 \\
\hline 6 & 7.22 & 0.477 & 883 & 623 & 200 & 115 & 13 & 66.13 & 8.42 & 213 & 110 & 105.05 & 1.082 & 2.2 \\
\hline 7 & 7.26 & 0.462 & 853 & 606 & 180 & 109 & 13 & 18.03 & 32.78 & 237.85 & 115 & 52.58 & 0.731 & 2.05 \\
\hline 8 & 7.42 & 0.366 & 684 & 484 & 165 & 90 & 12 & 36.07 & 18.18 & 152.65 & 95 & 46.16 & 8.68 & 2.15 \\
\hline 9 & 7.32 & 0.282 & 527 & 374 & 135 & 69 & 12 & 34.06 & 12.10 & 113.6 & 90 & 20.65 & 0.065 & 1.60 \\
\hline 10 & 7.45 & 0.502 & 919 & 659 & 260 & 118 & 6 & 46.09 & 34.17 & 216.55 & 200 & 12.26 & 0 & 0 \\
\hline 11 & 7.23 & 0.443 & 819 & 579 & 180 & 105 & 12 & 36.07 & 21.82 & 209.45 & 115 & 59.41 & 0.898 & 1.80 \\
\hline 12 & 7.22 & 0.357 & 634 & 467 & 160 & 100 & 12 & 36.07 & 16.92 & 230.75 & 90 & 53.69 & 1.293 & 2.55 \\
\hline 13 & 7.35 & 0.434 & 802 & 569 & 170 & 105 & 12 & 38.07 & 18.17 & 117.5 & 105 & 51.66 & 0.911 & 3.10 \\
\hline 14 & 7.02 & 0.356 & 663 & 470 & 155 & 86 & 11 & 26.05 & 21.83 & 159.75 & 95 & 85.52 & 1.600 & 1.97 \\
\hline 15 & 7.45 & 0.420 & 790 & 552 & 210 & 101 & 12 & 36.07 & 29.11 & 198.8 & 105 & 69.01 & 1.712 & 2.25 \\
\hline 16 & 7.43 & 0.416 & 775 & 549 & 170 & 99 & 12 & 38.07 & 18.17 & 191.7 & 95 & 54.21 & 0.200 & 0 \\
\hline 17 & 7.48 & 0.342 & 634 & 451 & 175 & 80 & 11 & 36.07 & 20.61 & 131.35 & 100 & 47.10 & 0.671 & 0 \\
\hline 18 & 7.14 & 0.433 & 806 & 571 & 185 & 99 & 12 & 36.07 & 23.04 & 170.4 & 95 & 75.65 & 1.323 & 2.65 \\
\hline Max & 7.48 & 0.502 & 919 & 659 & 260 & 118 & 15 & 66.13 & 34.17 & 237.85 & 200 & 105.05 & 8.68 & 3.1 \\
\hline Min & 6.94 & 0.271 & 501 & 357 & 135 & 62 & 6 & 18.03 & 8.42 & 106.5 & 90 & 12.26 & 0 & 0 \\
\hline Mean & 7.28 & 0.38 & 698.83 & 496.61 & 172.78 & 89.72 & 12.00 & 35.73 & 20.21 & 166.87 & 109.72 & 47.66 & 1.33 & 1.67 \\
\hline \multicolumn{15}{|l|}{ Kulathur } \\
\hline 19 & 7.44 & 0.343 & 640 & 452 & 160 & 73 & 14 & 36.07 & 16.96 & 138.45 & 125 & 20.24 & 1.685 & 0 \\
\hline 20 & 7.38 & 2.57 & 4380 & 3100 & 505 & 930 & 30 & 114.22 & 53.32 & 809.4 & 375 & 136.15 & 5.643 & 9.95 \\
\hline 21 & 7.36 & 2.56 & 4340 & 3900 & 460 & 840 & 30 & 36.07 & 89.86 & 1583.3 & 340 & 143.41 & 0 & 0.179 \\
\hline 27 & 7.24 & 0.062 & 109.1 & 77.3 & 50 & 20 & 2 & 10.02 & 6.06 & 60.35 & 30 & 13.54 & 0 & 0 \\
\hline Max & 7.4 & 2.6 & 4380.0 & 3900.0 & 505.0 & 930.0 & 30.0 & 114.2 & 89.9 & 1583.3 & 375.0 & 143.4 & 5.6 & 10.0 \\
\hline Min & 7.2 & 0.1 & 109.1 & 77.3 & 50.0 & 20.0 & 2.0 & 10.0 & 6.1 & 60.4 & 30.0 & 13.5 & 0.0 & 0.0 \\
\hline Mean & 7.4 & 1.4 & 2367.3 & 1882.3 & 293.8 & 465.8 & 19.0 & 49.1 & 41.6 & 647.9 & 217.5 & 78.3 & 1.8 & 2.5 \\
\hline \multicolumn{15}{|c|}{ Amaizhanchan } \\
\hline 23 & 7.4 & 0.148 & 275 & 196 & 125 & 34 & 6 & 20.04 & 18.2 & 49.7 & 80 & 14.06 & 1.289 & 0 \\
\hline 24 & 7.34 & 0.086 & 156.4 & 111 & 50 & 18 & 5 & 12.02 & 4.85 & 56.8 & 50 & 11.76 & 0 & 0 \\
\hline 25 & 7.38 & 0.099 & 182.5 & 130 & 75 & 21 & 5 & 16.03 & 8.48 & 49.7 & 55 & 11.28 & 0 & 0 \\
\hline 26 & 7.5 & 0.115 & 212 & 150 & 100 & 25 & 5 & 16.03 & 14.56 & 49.7 & 60 & 12.39 & 0 & 0 \\
\hline 30 & 7.45 & 0.113 & 210 & 149 & 105 & 25 & 3 & 20.04 & 13.34 & 53.25 & 50 & 10.15 & 0.085 & 0 \\
\hline 31 & 7.26 & 0.124 & 229 & 163 & 90 & 26 & 5 & 22.04 & 8.47 & 56.8 & 225 & 8.12 & 0.494 & 0 \\
\hline Max & 7.5 & 0.1 & 275.0 & 196.0 & 125.0 & 34.0 & 6.0 & 22.0 & 18.2 & 56.8 & 225.0 & 14.1 & 1.3 & 0.0 \\
\hline Min & 7.3 & 0.1 & 156.4 & 111.0 & 50.0 & 18.0 & 3.0 & 12.0 & 4.9 & 49.7 & 50.0 & 8.1 & 0.0 & 0.0 \\
\hline Mean & 7.4 & 0.1 & 210.8 & 149.8 & 90.8 & 24.8 & 4.8 & 17.7 & 11.3 & 52.7 & 86.7 & 11.3 & 0.3 & 0.0 \\
\hline \multicolumn{15}{|c|}{ Kannanmoola } \\
\hline 28 & 7.06 & 0.034 & 46.2 & 34.4 & 100 & 26 & 9 & 20.04 & 12.12 & 56.8 & 140 & 11.51 & 0 & 4.69 \\
\hline 29 & 7.46 & 0.109 & 205 & 144 & 125 & 23 & 4 & 20.04 & 18.2 & 56.8 & 20 & 9.92 & 0 & 0 \\
\hline Max & 7.46 & 0.109 & 205 & 144 & 125 & 26 & 9 & 20.04 & 18.2 & 56.8 & 140 & 11.51 & 0 & 4.69 \\
\hline Min & 7.06 & 0.034 & 46.2 & 34.4 & 100 & 23 & 4 & 20.04 & 12.12 & 56.8 & 20 & 9.92 & 0 & 0 \\
\hline Mean & 7.26 & 0.0715 & 125.6 & 89.2 & 112.5 & 24.5 & 6.5 & 20.04 & 15.16 & 56.8 & 80 & 10.715 & 0 & 2.345 \\
\hline
\end{tabular}


Table 3 continued

\begin{tabular}{|c|c|c|c|c|c|c|c|c|c|c|c|c|c|c|}
\hline Sample no. & $\mathrm{pH}$ & $\begin{array}{l}\text { Salinity } \\
\text { (ppt) }\end{array}$ & $\begin{array}{l}\mathrm{EC}(\mu \mathrm{s} / \\
\mathrm{cm})\end{array}$ & $\begin{array}{l}\text { TDS } \\
(\mathrm{ppm})\end{array}$ & $\begin{array}{l}\text { Total } \\
\text { hardness } \\
(\mathrm{ppm})\end{array}$ & $\begin{array}{l}\mathrm{Na}^{+} \\
(\mathrm{ppm})\end{array}$ & $\begin{array}{l}\mathrm{K}^{+} \\
(\mathrm{ppm})\end{array}$ & $\begin{array}{l}\mathrm{Ca}^{2+} \\
(\mathrm{ppm})\end{array}$ & $\begin{array}{l}\mathrm{Mg}^{2+} \\
(\mathrm{ppm})\end{array}$ & $\begin{array}{l}\mathrm{Cl}^{-} \\
(\mathrm{ppm})\end{array}$ & $\begin{array}{l}\mathrm{HCO}_{3}^{-} \\
(\mathrm{ppm})\end{array}$ & $\begin{array}{l}\mathrm{SO}_{4}{ }^{2-} \\
(\mathrm{ppm})\end{array}$ & $\begin{array}{l}\mathrm{NO}_{3}^{-} \\
(\mathrm{ppm})\end{array}$ & $\begin{array}{l}\mathrm{PO}_{4}{ }^{3-} \\
(\mathrm{ppm})\end{array}$ \\
\hline
\end{tabular}

\begin{tabular}{|c|c|c|c|c|c|c|c|c|c|c|c|c|c|c|}
\hline \multicolumn{15}{|c|}{ Amaizhanchan-Kannanmoola confluence } \\
\hline 32 & 6.94 & 0.33 & 614 & 438 & 160 & 58 & 14 & 38.07 & 15.74 & 106.5 & 105 & 18.53 & 0 & 4.9 \\
\hline 33 & 7.62 & 0.312 & 586 & 415 & 150 & 71 & 10 & 28.05 & 19.4 & 152.65 & 110 & 28.47 & 2.516 & 0.29 \\
\hline 34 & 7 & 0.144 & 271 & 193 & 90 & 25 & 6 & 30.06 & 3.6 & 49.7 & 80 & 15.32 & 0 & 0.979 \\
\hline $\operatorname{Max}$ & 7.62 & 0.33 & 614 & 438 & 160 & 71 & 14 & 38.07 & 19.4 & 152.65 & 110 & 28.47 & 2.516 & 4.9 \\
\hline Min & 6.94 & 0.144 & 271 & 193 & 90 & 25 & 6 & 28.05 & 3.6 & 49.7 & 80 & 15.32 & 0 & 0.29 \\
\hline Mean & 7.187 & 0.262 & 490.333 & 348.667 & 133.333 & 51.333 & 10 & 32.06 & 12.913 & 102.95 & 98.333 & 20.773 & 0.839 & 2.056 \\
\hline \multicolumn{15}{|c|}{ Sreekariyam Thodu } \\
\hline 22 & 6.37 & 0.153 & 315 & 204 & 120 & 34 & 9 & 16.03 & 19.42 & 188.15 & 55 & 23.93 & 0 & 0 \\
\hline
\end{tabular}

(a)

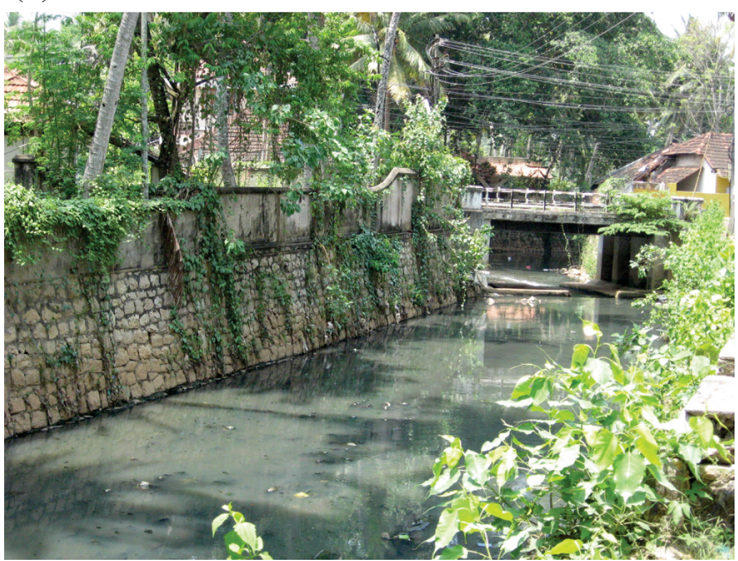

(c)

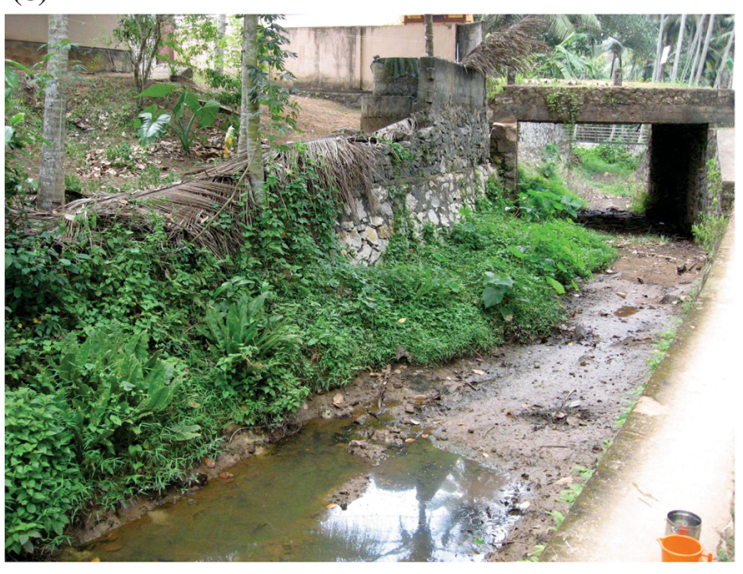

(b)

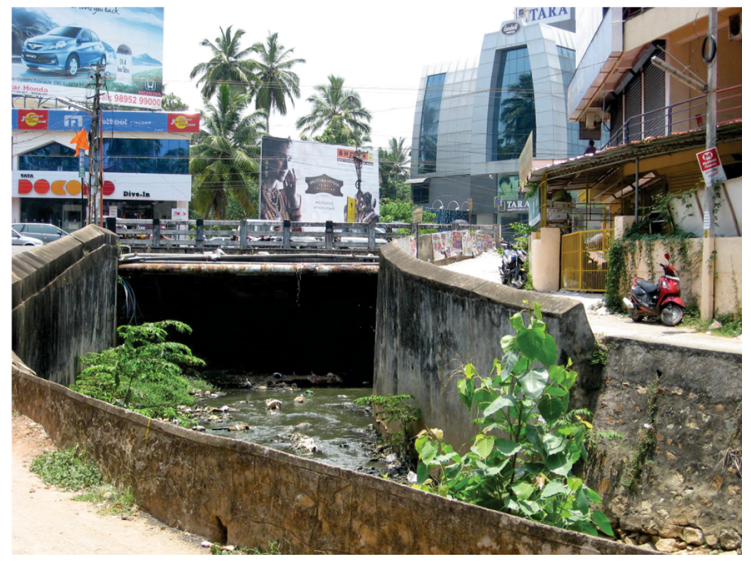

(d)

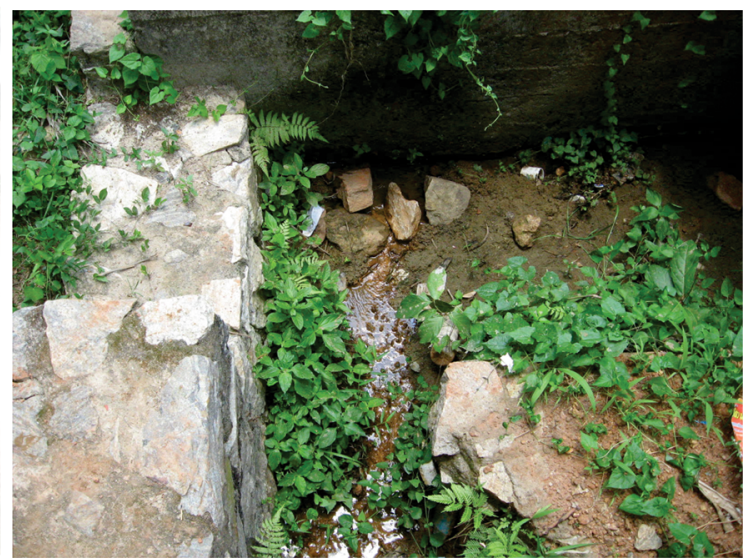

Fig. 2 a Stream flowing through Kannanmoola. Note the contamination, b stream flowing through Plamoodu. Note the contamination, $\mathbf{c}$ water stagnation near Kuzhikattukonam, d water stagnation near Maruthur 


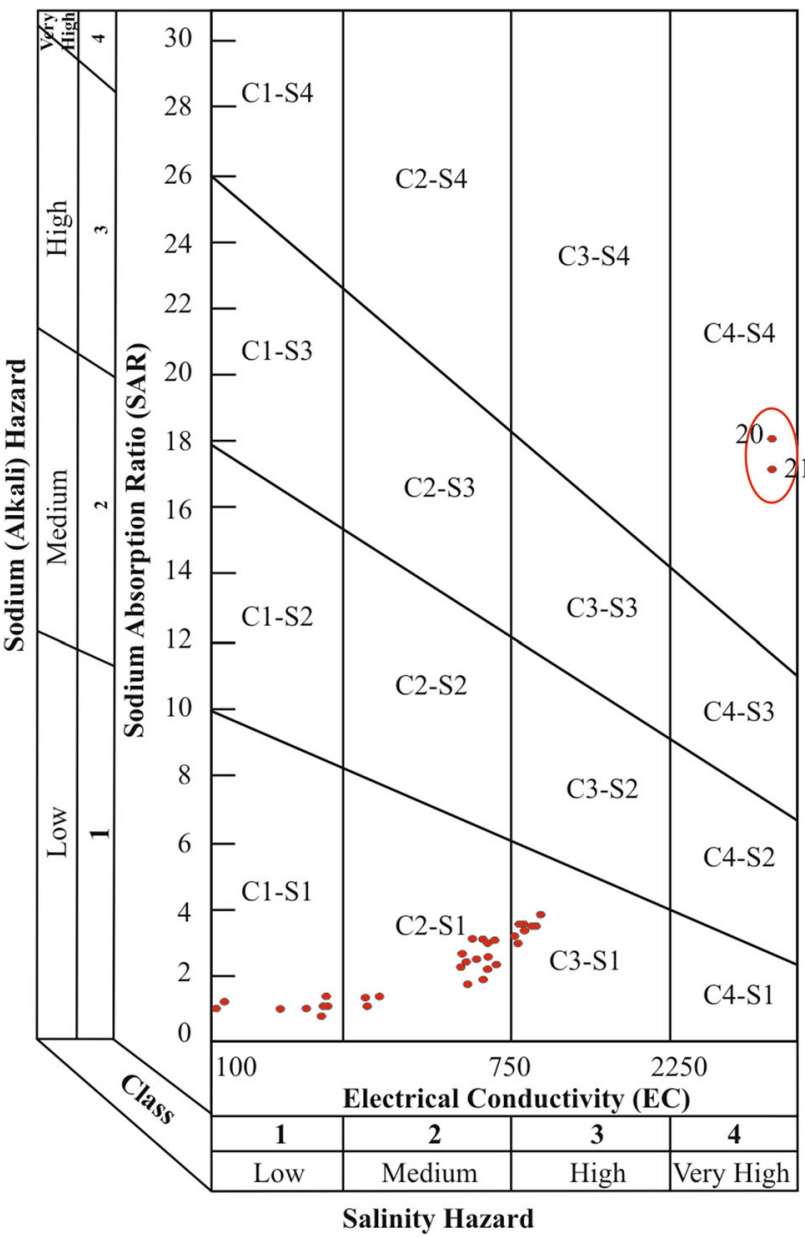

Fig. 3 US salinity diagram: samples are in low-sodium category and in different salinity category. Samples 20 and 21 show exception which are collected from the upcoming urban agglomerate

effluents find its final destination in the streams which ultimately debouch into the Veli-Akkulam Lake. The high content of solid and liquid waste material will change the water's natural colour, odour, taste, turbidity and temperature. Hence, these waters cannot be used for drinking and domestic purposes. This polluted water on entering the lake will also lead to eutrophication.

Figure 2a-d shows four different streams that drain to the Veli-Akkulam Lake. Figure 2a shows the stream which flows through Kannanmoola. Water from this stream is highly polluted with waste materials and has a pungent smell and is light black in colour. Sample no 34 represents this stream. The water is turbid and slightly hard in nature. It is not suitable for drinking and domestic purposes. Most of the solid waste materials are dumped into the stream, thereby polluting its water. Figure $2 b$ shows the stream which flows through Plamoodu, and sample no 28 represents this. The water from this stream shows pungent smell and is black in colour. It is slightly turbid and hard in nature. Figure 2c, d (represented by sample nos 25 and 30, respectively) depicts water scarcity. The excess quantity of waste dumped has resulted in stagnation of water, and its free flow of water has been hampered. This results in water scarcity in the further downward traverse of some streams. This stagnation also promotes breeding of mosquitoes.

Variations in other physical parameters are also mainly attributed to anthropogenic activities. The larger variation in EC (from 46.2 in sample 28 to $4380 \mu \mathrm{s} / \mathrm{cm}$ in sample 20) is mainly attributed to anthropogenic activities as well as to the geochemical processes prevailing in this region. Hardness of the water samples also varies among moderately hard, hard and very hard (from 50 in sample 27 to 505 sample 20) precluding the use of the water for drinking, domestic or irrigation purpose. Samples 20 and 21 are the most polluted ones. These samples were collected from two adjacent streams at Kazhakuttom. These streams are sites of poultry and live stock waste disposal, in addition to the usual wastes. To find out the suitability of water for domestic, drinking and irrigation purposes, the data have been plotted on US Salinity Laboratory (Fig. 3), Wilcox (Fig. 4) and Hill Piper (Fig. 5) diagrams, and this shows that most of the water samples in the study area are unfit for various purposes. In the US salinity diagram, except samples 20 and 21 , all the samples fall in low-sodium hazard area. Similarly in Wilcox diagram, except the same samples 20 and 21, rest of the samples fall in very good to good fields. The ionic distribution present in the water sample can be determined by using Hill Piper diagram. Based on this diagram, it is recognized that most samples are under the sodium chloride type.

\section{Spatio-temporal changes of Veli-Akkulam Lake}

The spatio-temporal changes of Veli-Akkulam Lake and changes in the land-use/land-cover pattern of adjacent areas, over a period of 61 years, were extracted from the Survey of India topographic sheets and Google Earth Imagery (Fig. 6). Table 4 shows the variation in the areal extent of this lake over time. The lake shows a small change in the areal extent from 1942 to 1990 . But there was a contrasting change in the areal extent of the lake between 1990 and 2013 which is a real matter of concern. Comparative studies point out that the shrinkage of area is more than $28 \%$ during this short period owing to the real boom of urbanization and increase in population (Table 5). It was 
Fig. 4 Wilcox diagram: samples are in very good to good category except samples 20 and 21

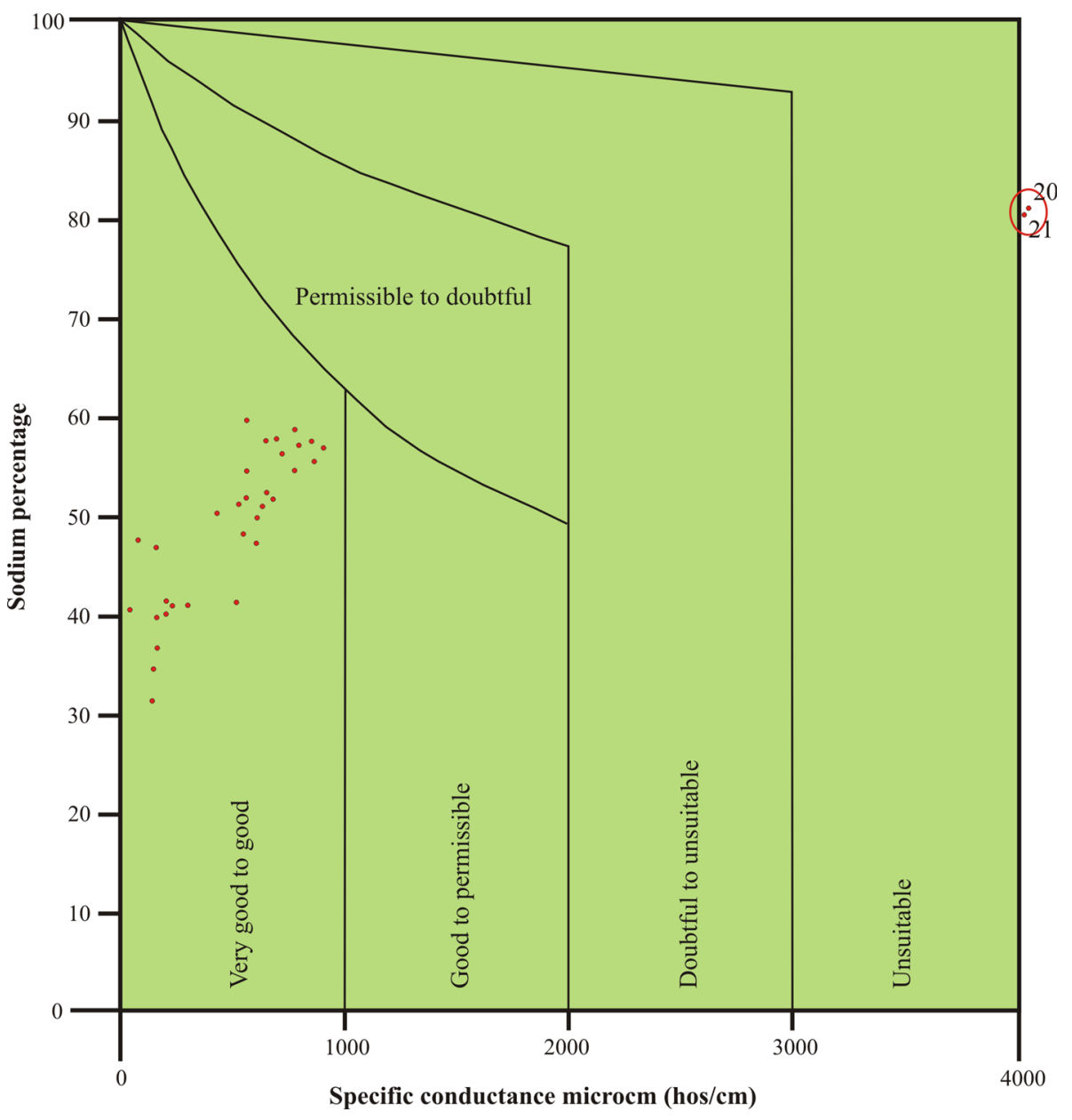

during this period the real boom of urbanization occurred. The most striking intervention is the conversion of flood plains of the lake into large and small settlements. The wetland areas have witnessed reclamation (Fig. 7a). Numerous multi-storied buildings started mushrooming in the wetlands during this period (Fig. 7b). As a result only a few stretches of wetlands are seen today. Beyond the geological phenomena of the shrinking of lakes, the aggravated human interference played a major role in shrinking the lake and its flood plains. Due to the lack of bathymetric data, the changes in the depth were not analysed. The reclamation activity in the lake areas has resulted in the reduction in the original capacity or areal extent of the lake.

\section{Land-use changes in and around Veli-Akkulam Lake}

Spatio-temporal changes in land-use and land-cover are common in any urbanized region. An analysis of different temporal data will give an idea about these changes.
Figure 8 and Table 6 show the change in the areal extent of different land-use/land-cover classes between 1942 and 2013. The study reveals that coastal alluvium, wetlands and mixed cultivation with settlements were the major landcover during earlier days. Moreover, the earlier maps show that roads were fewer and most of the land was covered by mixed cultivation with settlements. The major cultivation of these areas was coconut, mango, jackfruit and cashew plants. The coastal tract was completely occupied by coconut trees.

Now, the entire coastal alluvium, present very close to the lake, has been converted into settlement with mixed cultivation. Residential establishments increased exponentially. Widening and construction of new roads took place. The Thiruvananthapuram City by-pass road from Kazhakkuttam to Kovalam has led to the bifurcation of certain water bodies and marshes and truncated many lower-order streams, thereby reducing water infiltration, increasing water-logging condition along a few stretches (Muraleedharan and Muraleedharan 2002) as well as blocking the coast perpendicular drainage systems which 
Fig. 5 Hill Piper diagram: Samples spread in almost all types with sodium chloride type dominating

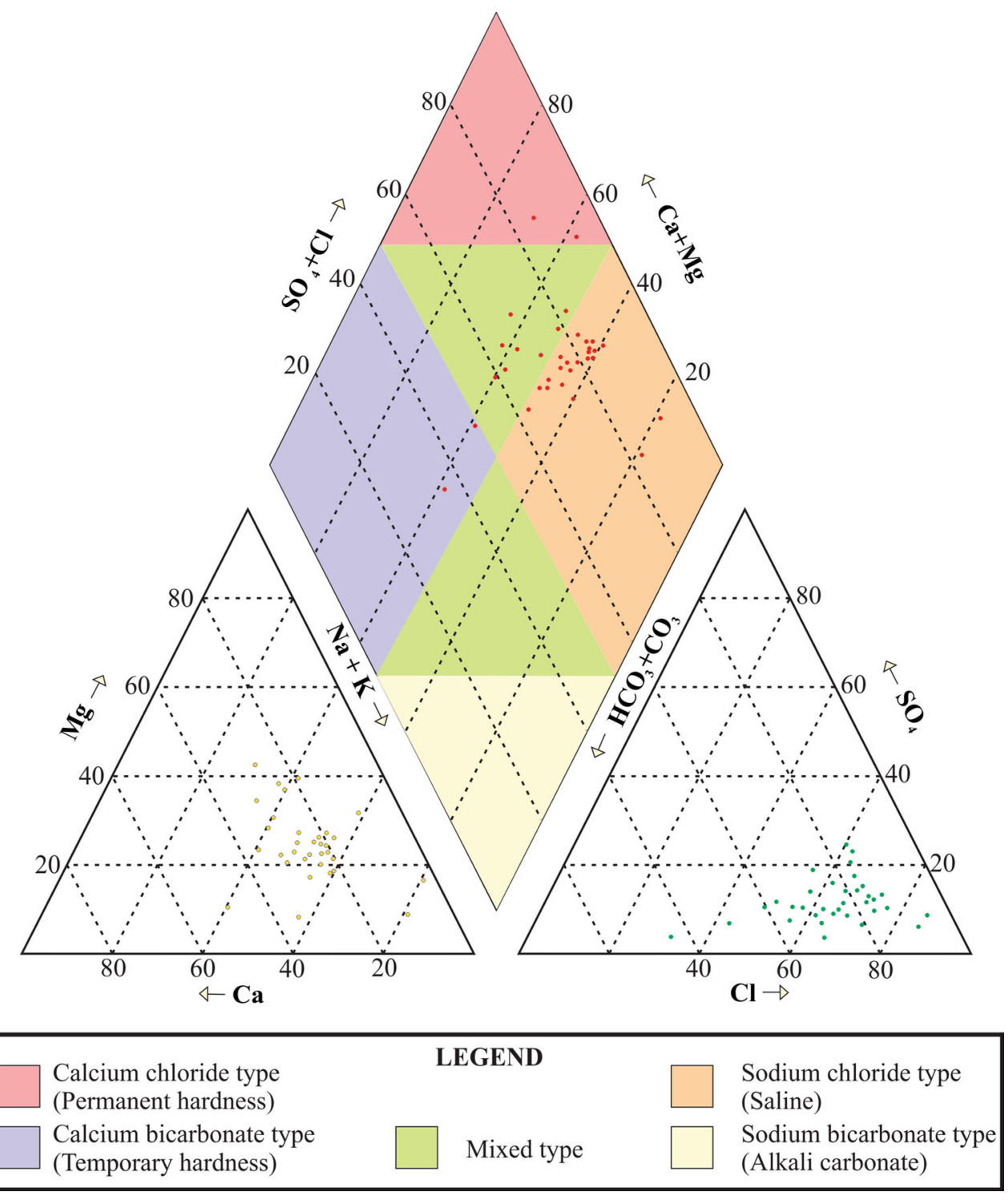

are generally natural pathways for excess surface water to get drained off during heavy monsoon. Many of the multistoried buildings, industrial establishments such as Technopark, Vikram Sarabhai Space Centre (VSSC), factories, air force academy and boat club are situated in the area. These offices and industries have created a lot of employment opportunities, and hence, people from nearby suburban and rural areas have migrated and settled down in the urban areas. This increase in population might be the main reason for the change in the land-use pattern. Moreover, factories and industries have also played some role in the formation of barren or waste land in their adjoining areas. Agricultural land has been replaced to a large extent by either settlements or industrial establishments. Increase in various types of human activities has resulted in increase in waste dumping. Large-scale construction of apartments and flats are quite common now days, so sewages are directly opened to the surface water system, which in turn contaminate the lake.

\section{Conclusions}

The hydrogeochemistry of the lake and its feeding system were studied by the analyses of water samples by various analytical methods and comparison with the BIS standards. Based on the hydrogeochemistry, it is revealed that most of the stream water samples contain normal content of cations and anions in the upstream portion and gradually there is a gradual deterioration in the quality as it flows through the agglomeration. This is pictorially shown in Fig. 9. Thus, the main natural channels draining into the lake have been 
Fig. 6 Spatio-temporal changes of Veli-Akkulam Lake

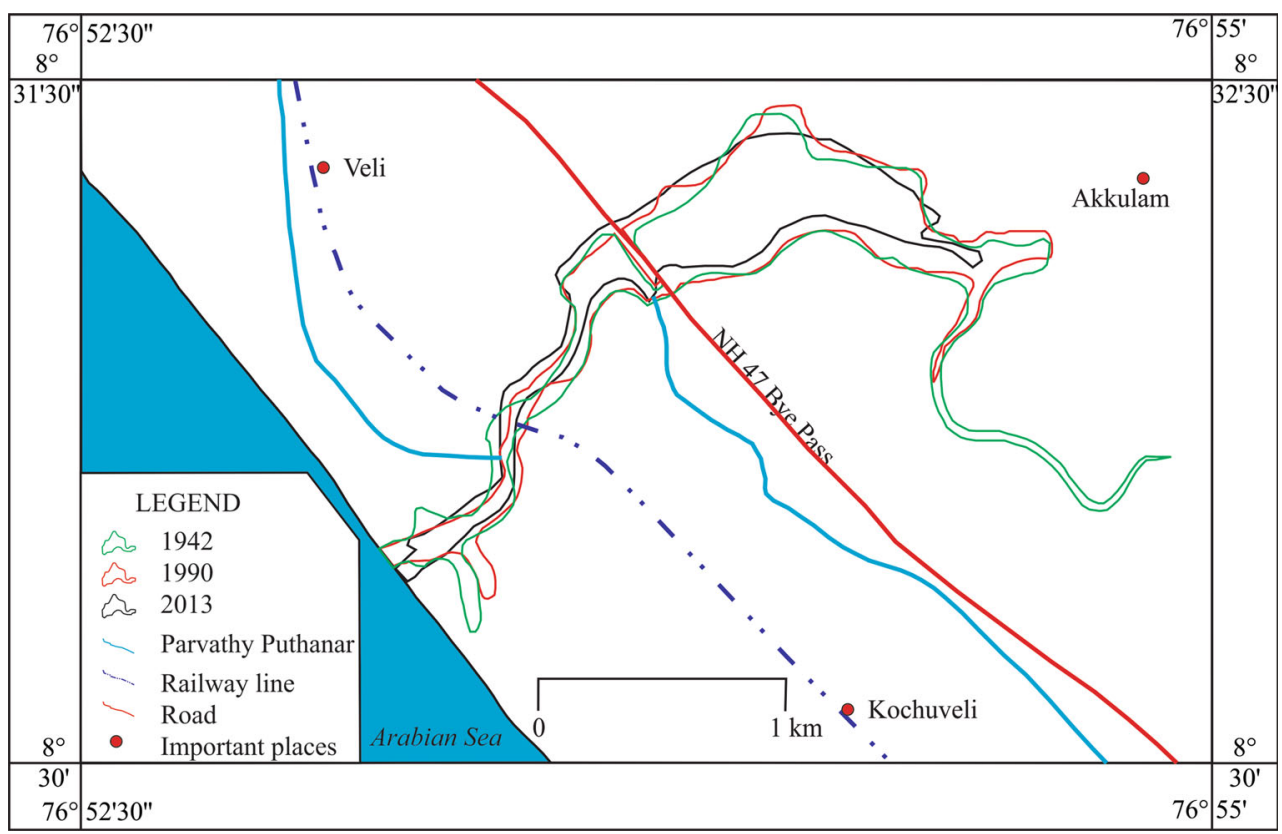

Table 4 Spatio-temporal changes of Akkulam Lake with respect to the year 1942

\begin{tabular}{lll}
\hline Year & $\begin{array}{l}\text { Area } \\
\text { (sq.km) }\end{array}$ & $\begin{array}{l}\text { \% change with } \\
\text { respect to 1942 }\end{array}$ \\
\hline 1942 & 1.608 & - \\
1990 & 1.576 & 2.00 \\
2013 & 1.157 & 28.05 \\
\hline
\end{tabular}

Table 5 Population of Thiruvananthapuram municipal corporation

\begin{tabular}{lllll}
\hline & $1981^{\mathrm{a}}$ & $1991^{\mathrm{b}}$ & $2001^{\mathrm{c}}$ & $2011^{\mathrm{c}}$ \\
\hline $\begin{array}{c}\text { Thiruvananthapuram } \\
\text { corporation }\end{array}$ & $4,83,086$ & $6,46,372$ & $8,89,635$ & $10,48,283$ \\
\hline
\end{tabular}

Source: Census of India (1981, 1991, 2001, 2011)

a Area was 141.74 sq.km

b Area was 177.77 sq.km

c Area was 216.36 sq.km

changed into a major source of pollutants. These streams contain sewage wastes, poultry wastes and waste from households. These streams together with other streams have resulted in the high concentration of ions in the lake water. In some portions of the lake, high amount of the algal contents are seen giving an indication of a minor eutrophication.

Spatio-temporal study of lake and its land-use/landcover shows that the pressure of the population has resulted in the shrinkage and alteration of this wetland system
(Fig. 10). It is identified that most of the coastal alluvium is gradually being occupied by small- and large-scale buildings. Wetlands have also changed due to reclamation activities. As the years pass, a lot of adverse changes are happening in the land-use and land-cover pattern in and around Veli-Akkulam Lake. Agricultural land has been replaced to a large extent by either settlements or industrial establishments. The reclamation activity in the lake area has resulted in the reduction in the original basin capacity.

Since the lake and the adjacent wetland system are under a threat of eutrophication, a few measures are suggested to prevent the lake from further eutrophication.

1. Awareness to people that the lake is under the threat of unfettered pollution and this will affect their lives also.

2. Streams should be freed from being sites of waste dumping.

3. Remove all waste material from the water by using technical and chemical methods.

4. Keep the lake's drainages clean and neat, and this will increase the storage capacity and quality of the water in the lake.

5. Sediments that enter into the lake can be reduced by greening and afforestation in the hinterland, and the status quo of the basin capacity maintained by periodic dredging.

6. Quality monitoring of water needs to be done periodically in months or every year.

7. Improper land-use in and around the lake must be curtailed, thereby preserving the current areal extent of the lake. 
(a)

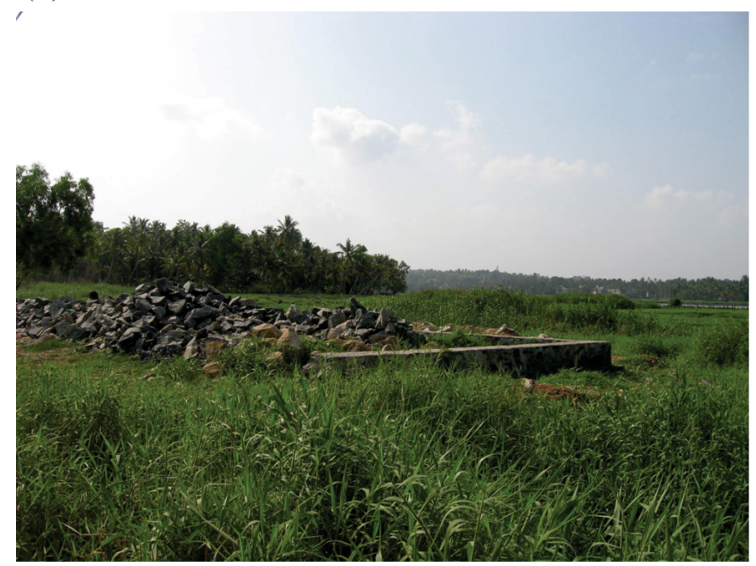

(b)

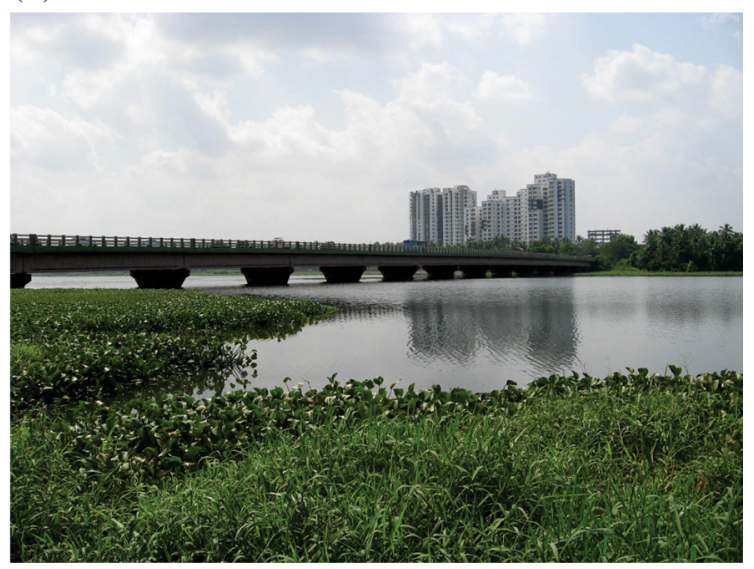

Fig. 7 a Reclamation of wetlands in progress, b skyscrapers occupying the wetlands

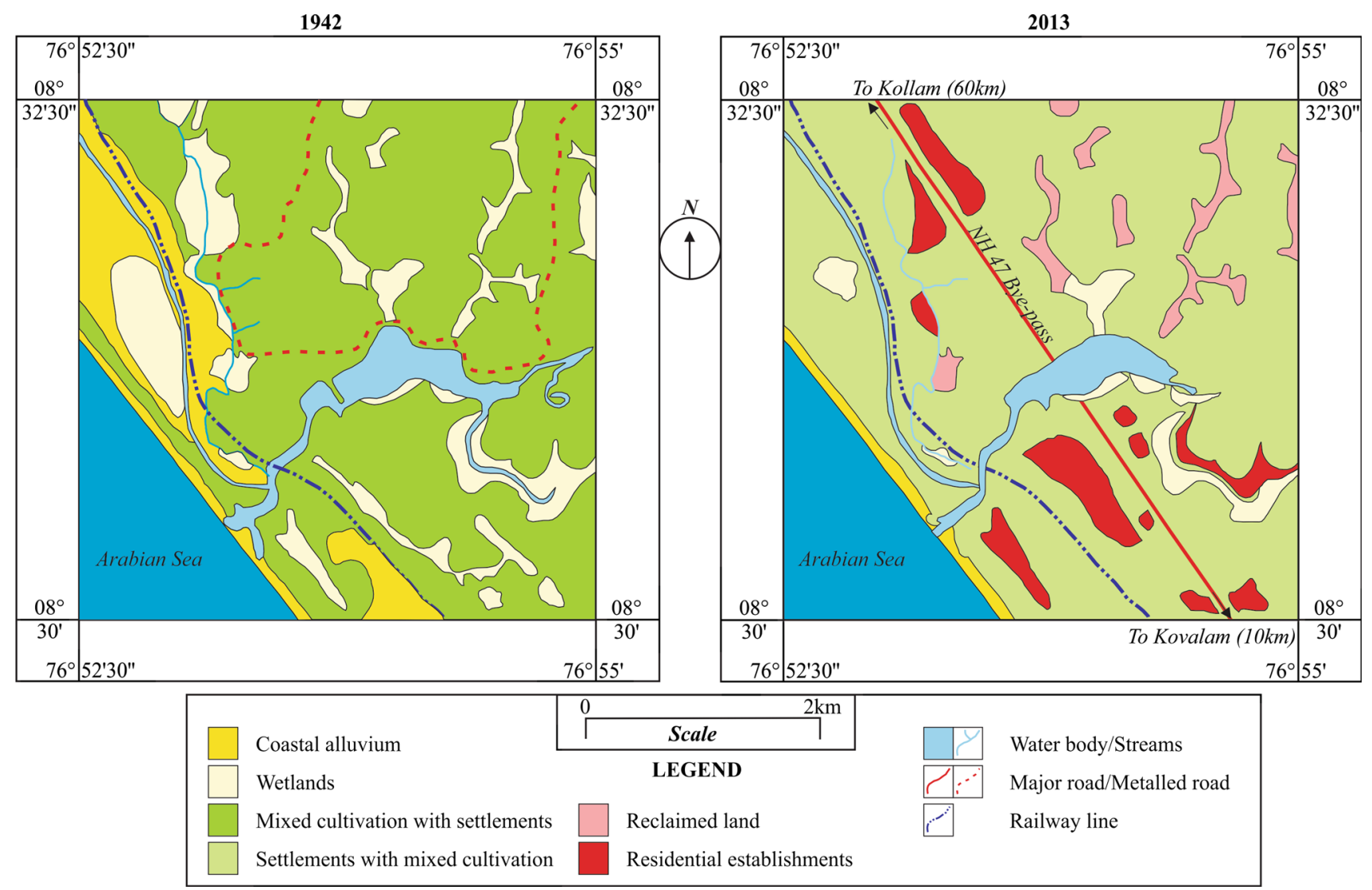

Fig. 8 Land-use/land-cover changes in and around Akkulam Lake (1947-2013)

Proper management of waste and land-use and landcover in and around Veli-Akkulam Lake will prevent water pollution to a great extent. This will help retain the areal extent of the lake. Reduced waste material entering into the lake will also reduce the dissolved solids and ionic content of the water. This in turn will prevent the possible eutrophication of the lake also. This will increase the irrigation and domestic quality of the water. So the lake water can be used for irrigation while it is free from pollution, and also it can be used for domestic and drinking purposes. Using the simple pollution prevention steps is an economical way to tackle the deterioration of this once pristine backwater. Effective management must ensure that the best use is made of available supplies, including 
Table 6 Change in land-use/land-cover between 1947 and 2013

\begin{tabular}{llll}
\hline Land-use/land-cover & 1942 (area in sq.km) & 2013 (area in sq.km) & Change in land-use/land-cover (\%) \\
\hline Coastal alluvium & 2.186 & 0.308 & 14.10 \\
Wetlands & 2.969 & 1.125 & 37.81 \\
Mixed cultivation with settlements & 13.136 & & 100 \\
Reclaimed land & & 1.448 & 15.761 \\
Settlements with mixed cultivation & & 18.742 & \\
Total area (sq.km) & 18.291 & & \\
\hline
\end{tabular}

Increase in area from 1942 to 2013 is due to the shrinkage of lake

Fig. 9 Pictorial representation of changes of ions throughout the traverse of feeder streams

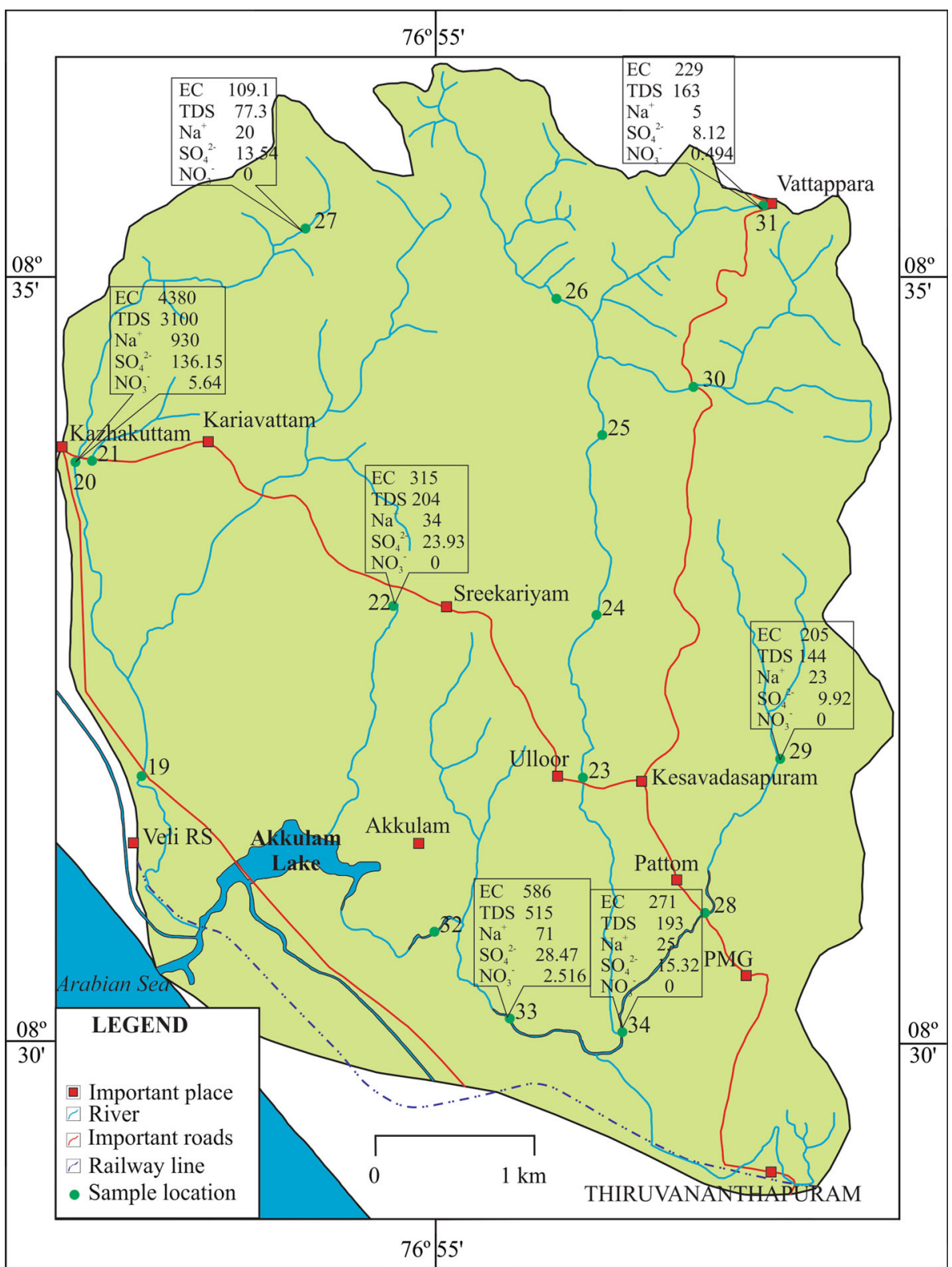


(a)

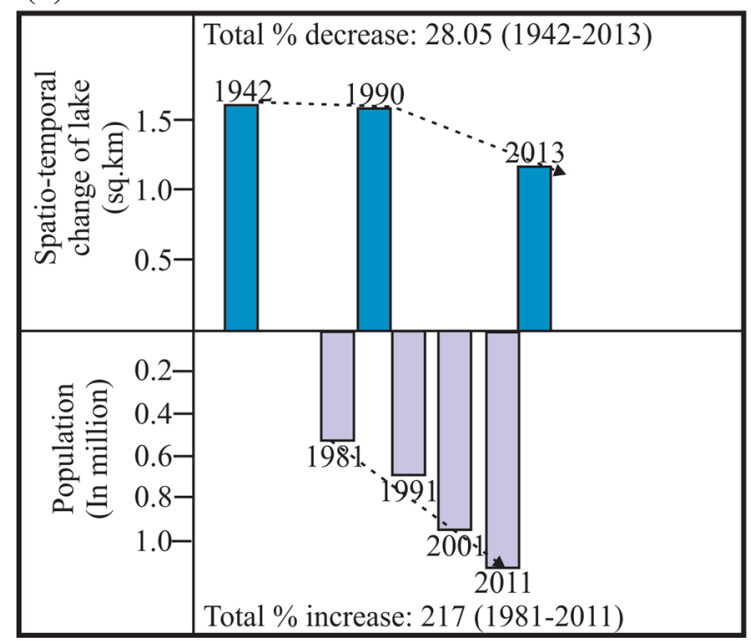

(b)

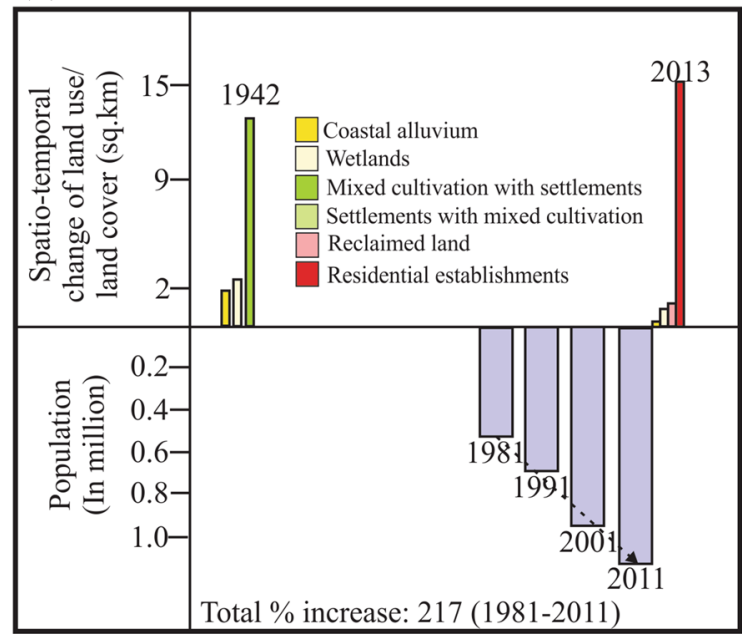

Fig. 10 Spatio-temporal change of lake vis-à-vis increase in population

protection from pollution, and should seek to limit conflicts over access to freshwater. This calls for the establishment of clearly defined policies and strategies as well as the development of enforceable mechanisms and tools for water pollution control.

Acknowledgments AR acknowledges Dr. SN Kumar, Head of the Department of Geology, University of Kerala, Thiruvananthapuram, for providing facilities to carry out laboratory work. This work was part of AR's MSc dissertation and hence thank all classmates for their encouragement. The dissertation was also reviewed by Dr. SN Kumar, when AR's supervising teacher Dr. Sajinkumar KS was away for the Arctic Expedition.

Open Access This article is distributed under the terms of the Creative Commons Attribution 4.0 International License (http:// creativecommons.org/licenses/by/4.0/), which permits unrestricted use, distribution, and reproduction in any medium, provided you give appropriate credit to the original author(s) and the source, provide a link to the Creative Commons license, and indicate if changes were made.

\section{References}

APHA (1989) Standard methods for the examination of water and waste water. American Public Health Association, Washington, D.C.

BIS (1991) Indian Standard specification for drinking water. Bureau of Indian Standards, New Delhi

Bruckner H (1989) Late Quaternary shorelines in India. In: Scott DB, Pirazzoli PA, Honig CA (eds) Late Quaternary sea-level correlation and applications. Kluwer Academic Publications, Dordrecht, pp 169-194

Divya KP (2007) Methane emission from Akkulam Lake, TvpmDiurnal pattern, Ph D. Thesis (unpubl), Catholicate College, Pathinamthitta
Muraleedharan C, Muraleedharan MP (2002) Report on geo-environmental appraisal of coastal tracts of Thiruvananthapuram and Kollam Districts of Kerala for studies on hazard zonation and water pollution. GSI (unpublished report)

Muraleedharan Nair MN, Ramachandran KK, Harish CM, Narayanaswami, Muraleedharan V, Mohanan CN, Ahalya Sukumar (1998) Integrated environmental assessment of Akkulam Veli Lake. Report submitted to Kerala State Committee on Science and Technology and Environment, December 1998, CESS, Thiruvananthapuram

Nair KK (2007) Quaternary geology and geomorphology of the coastal plains of Kerala. Geological Survey of India, Calcutta

Nair KM, Padmalal D, Kumaran KPN, Sreeja R, Limaye RB, Srinivas R (2010) Late quaternary evolution of Ashtamudi and Sasthamkotta Lake systems of Kerala, south west India. J Asian Earth Sci 37:361-372

Nayar S, Nayar NM (1997) Wetlands. In: Thampi KB, Nayar NM, Nayar CS (eds) The natural resources of Kerala. WWF State Office, Trivandrum, Kerala

Padmalal D, Kumaran KPN, Nair KM, Baijulal B, Limaye RB, Mohan VS (2010) Evolution of the coastal wetland systems of SW India during the Holocene: evidence from marine and terrestrial archives of Kollam coast. Kerala. J Q Int 237:123-139

Piper AM (1953) A graphic procedure in the geochemical interpretation of water analysis. USGS, Washington DC

Ravindrakumar GR, Rajendran CP, Prakash TN (1990) Charnockitekhondalite belt and tertiary-quaternary sequences of Southern Kerala. Geological Society of India, Bangalore

Sabu J, Thrivikramji KP (2002) Kayals of Kerala coastal land and Implication to quaternary sea level changes. Memoir Geol Soc India 49:51-64

Salini G (2007) Heavy metal pollution monitoring on Ponmudi, Akkulam, Cherthala and Munnar using Lichens-A case study, $\mathrm{Ph}$ D. Thesis (unpubl), SreeSankara College, Kalady

Sheela AM, Letha J, Joseph S (2011) Trophic state index of a lake system using IRS (P6LISS III) satellite imagery. Environ Monit Assess, Springer, Netherlands 177(1-4):575-592

Sheela AM, Letha J, Joseph Sabu KK, Ramachandran, Justus J (2013) Detection of extent of sea level rise in a coastal lake system using IRS satellite imagery. Water ResourManage. doi:10.1007/ s11269-013-0309-0 
Slimmings GL (1997) Soil study: Akkulam Village, Kerala. Report submitted to soil survey kerala. March 1997, Thiruvananthapuram

Soman K (2002) Geology of Kerala. Geological society of India, Bangalore

Swarnalatha K, Letha J, Ayoob S (2012) An investigation into the heavy metal burden of Akkulam Veli Lake in South India. Environ Earth Sci 68:795-806
Thrivikramji KP, Joseph S, Narayana AC (2007) Coastal wetlands of Kerala: origin and evolution. In: Proceedings Kerala environment congress, pp 36-48

US Salinity Laboratory (USSL) Diagram (1954) Diagnosis and improvement of saline and alkali soils, USDA Handbook No. 60, U.S., GPO, Washington, D.C., USA

Wilcox LV (1955) Classification and use of irrigation waters. US Department of Agriculture, Washington, DC 